\title{
An Investigation into the Effectiveness of Public Middle Level Technical Training Colleges in Central and Eastern Provinces in Kenya
}

Ngatiah Simon Nderitu

Mount Kenya University

\author{
Doi:10.5901/jesr.2014.v4n1p245
}

\begin{abstract}
Technical and vocational education has been looked upon as a catalyst of economic development and social transformation (Republic of Kenya, 1965). It should supply artisan, crafts, technicians required for industrialization of a nation. The training in TIVET need to ensure that there is adequate supply of properly trained human resource to enable industries to perform in line with vision 2030 of acquiring a suitable economic growth (MoEST, 2007). However, parents and employers and other stakeholders have been dissatisfied with TIVET trainees' performance in national examinations and the level of competence achieved by TIVET graduates. By 2002, industries were querying the competence of graduates from TIVET and even went to the extent of training their own (TIVET Audit Report, 2003; MoEST, 2007). TIVET have been dogged by performance problems. Despite this, many studies continue to be done to investigate factors that cause poor performance in primary and secondary level with TIVET institutes having had little or no research done on their poor performance in Kenya. There was need therefore to get information on what factors contribute to the poor academic achievement (ineffectiveness) that consequently lead to low completion rate among middle level technical training colleges. The research went a step further to establish what should be done to improve effectiveness in these institutions.
\end{abstract}

\section{Introduction}

The training activities in the informal sector are characterized by on- the job training to develop vocational and technical skills largely for small scale operations, labour intensive and adaptive technology (Republic of Kenya, 1988). Rapid technological changes, coupled with need for economic growth and development require workers with more flexibility and a deeper theoretical knowledge of their occupation. This necessitates training or retraining workers fast and with relevant skills and attitudes to meet the changing labour market demands for skilled manpower necessary for socioeconomic development. In Kenya, technical and vocational training centres have been established to add to and reduce the inadequacies for on-the job training.

Moreover participation in education and training is one aim of education in any country. A country that lags behind in the number of trainees joining education and training institutions or in the number of trainees passing important national examinations, may fail to effectively participate in technological development (Eshiwani, 1983).The economic development of such a country is also likely to be retarded. To achieve expansion in the industrial sector requires trained technicians, moreover venturing into commerce demands certain basic skills and training.

The training centres should provide quality education and training, for the training could make its most direct contribution to economic growth by improving the quality of labour. A UNESCO Conference (2003),in Mauritius noted that Kenya's aim in technical, vocational education and training policy is to improve the quality of training at all levels so that the quality of trained human resource can enhance and sustain a high level of economic development, which would in turn, improve the quality of life by raising the standards of living.

Formal vocational training provides needed skills for the economy that cannot be offered elsewhere more efficiently. Moreover, on- the job training does not supply all the skilled labour needed for a country's economic growth, and enhancing the achievement of policy priorities on economic recovery for wealth and employment creation. In addition, beyond a certain level of sophistication, trade skills demand a theoretical foundation in order to be understood and properly applied. The abstract knowledge that provides a sound basis for training in sophisticated labour skills is best imparted in the classroom, hence the need to embrace TIVET that provide required skills and technology (Republic of Kenya, 2005).

MacKay (1981) noted the need for middle level managers, technicians, craftsmen as well as skilled artisans who are required to turn the national economy and usher in the desired technological advancement elevating Kenya from a 'consumer' nation to a 'producer' nation. He recommended for the abolition of technical secondary schools and 
converting them to technical training colleges to produce a mass of middle level skill women and men, for such have assisted in the industrial process in the fast growing economies of East Asia and in industrialized countries like Germany, Canada by providing highly functional and practical oriented middle level human resource. From Mackay (1981) recommendation, expansion and enrolment rates in training colleges have not lagged behind, for example, enrolment in public TIVET rose from 45,076 in 2001 to 68,379 in year 2005 (Republic of Kenya, 2006).

Despite the marked enrolment in vocational and training institutions, the programme has had some marked shortcomings (Republic of Kenya, 2001). The TIVET institutions have been characterized by significantly low proportion of the trainees who graduate. Trainees' performances in national examinations have largely been poor in these middle level training colleges. The examination performance at the national level is not good as shown in table 1 . Those who were registered in 2002, only $42.3 \%$ passed, in 2003 , only $40.6 \%$ passed, in 2004 , only $45.8 \%$ passed, in 2005 , only $42.9 \%$, and in 2006 , only $49.2 \%$ passed. TIVET performance has remained steady and being consistently below $50 \%$ pass since the early 2000s. This indicates that large numbers of TIVET trainees do not successfully complete their training. The poor performance in national examinations casts doubt on effectiveness of TIVET in preparation of trainees for industry and nation building at large. Table 1.1 depicts national results in TIVET for five years.

Table 1.1 Analysis of technical examination results 2002 -2006 July Series

\begin{tabular}{|c|c|c|c|c|c|}
\hline Year & Entry & Pass & Refer/Absent & Fail & \% pass \\
\hline $\mathbf{2 0 0 2}$ & 3703 & 1568 & 1530 & 605 & 42.3 \\
\hline $\mathbf{2 0 0 3}$ & 4360 & 1771 & 1769 & 820 & 40.6 \\
\hline $\mathbf{2 0 0 4}$ & 4262 & 1954 & 1551 & 757 & 45.8 \\
\hline $\mathbf{2 0 0 5}$ & 5133 & 2203 & 1883 & 1047 & 42.9 \\
\hline $\mathbf{2 0 0 6}$ & 6119 & 3016 & 2347 & 756 & 49.2 \\
\hline
\end{tabular}

Source: KNEC, 2007

The ability to respond to the challenges of the changing times depends on the populace educational and training achievements (Republic of Kenya, 1988). Consequently the technical training sector has a big role to play in the supply of a well-educated and trained workforce critical to the success of Kenya's industrialization process necessary for the economic development. In regard to this; failure to improve performance in TIVET perpetually compromise the required human capital accumulation and jeopardize Kenya's economic recovery. Economic growth will also prove elusive with small proportions of labour force successfully completing technical education as a result of the quality of education and training in TIVET. On the other hand provision of appropriate learning experiences and quality industrial education and training programme could increase productivity and significantly improve the country's fortunes (Ministry of Science and Technology, 2007).

The performance in TIVET has been relatively poor as indicated by performance in national examinations, compared to expectations of the parents and the nation at large (KNEC, 2007). In spite of this, enrolments and financial support in these institutions continue to rise (MoEST, 2007). The training in TIVET requires substantial investment and financial resource allocation from parents, community and government. For example, the governments allocation towards recurrent and development expenditure in TIVET rose from 888.34 million year 2001/2002 to 1476.09 million year 2005/2006 (Economic Survey, 2006) - the 66.5\% increase in financial allocation from the government without considering other financiers is quite a heavy sacrifice. It is this realization -questionable education and training quality as shown generally by national examination performance (Table 1.1) plus the heavy financial allocation (Economic Survey, 2006) that calls for a study in the area of factors influencing effectiveness among public middle level TIVET colleges with the expectation that the findings will yield recommendations beneficial to sound educational planning and how best to improve performance in these institutions.

\section{Factors Influencing Effectiveness among TIVET Colleges}

The right education and training can be achieved through the provision of an inclusive and quality education which is accessible and relevant to all Kenyans. Gardner (1961) argues that quality of education can be measured in terms of achievement or non-achievement of the goals that a particular education system has set - say academic performance. Teachers, buildings, equipment, administrators could be factors only there to assist the system to achieve the goals that it has set itself. On this premises, proper administration of educational training institutions, provision of right training force and adequate training facilities are variables essential to enable effective provision of education and training. Coupled 
with these, is the need to enrol trainees with the right characteristics in terms of motivation and discipline. Eshiwani (1983) referring Shiefelbein and Simmons (1981) highlights the determinants of school achievement in developing countries as, school resources and management; teachers' and learners' characteristics.

\section{Educational Administration and Supervision of TIVET}

Supervision, understood, as the instructional improvement of schools and teachers is a task of both the ministerial and institutional levels and is carried out by educational officers and institute administrators. School administration and supervision play very important role in academic achievement in schools. Internal as well as external criteria and mechanism for monitoring progress are necessary for teachers. Hopkins et al (1997) underscore the necessity of directing supervisory efforts at the learning institutions. In a study carried out in Pakistan, they note that the supervisor can introduce new instructional strategies, learning materials, management approaches or mentoring in the whole institution desirable for better performance.

Mbithi (2007) observes supervision as one of the basic requirements in administration. It encompasses the tactics of efficient and proper management of personnel. It is concerned with those aspects of administration, which are aimed at maintaining employees' commitment to organization goal. As such supervision is sensory system in an organization. The supervisor must give clear directions to the workers concerning what to do and how to do it.

Olembo et al (1992) argue that supervision can be generally conceptualized in two functional ways; overseeing and helping. The overseeing function of supervision involves directing, controlling, reporting, commanding and other such activities that emphasize the task at hand and the extent to which particular objectives have been accomplished by subordinates. In Kenya, overseeing has been delegated to the inspectorate, the professional arm of the MOEST. Personnel at the inspectorate engage in various activities,_which could be collectively term ed as supervision. Whereas overseeing involves checking that work is done, helping function involves the actual daily routine of doing the work. The helping aspect of supervision involves facilitating, supporting, guiding and assisting trainers to grow professionally. An outcome of this growth should be the improvement of the teaching-learning process.

Supervision is an administrative activity whose strategy is to stimulate teachers toward greater pedagogic effectiveness and productivity (Okumbe, 1998). It is a means toward an end whose major supervisory activities include planning, organizing, coordinating, influencing, communicating and evaluation.Planning entails identification of the objectives of the educational organization or institutes and the means by which they can be achieved. A supervisor helps in the initiation of action for the achievement of individuals or group goals. Under organizing, supervisory leadership helps in the division of work and assignment of duties for the achievement of the educational objectives. It is the obligation of the supervisors to train and develop their teachers and other subordinates so that the constantly recurring departmental problems can be solved efficiently and effectively. Co-ordination involves supervisors striving to promote an effective working relationship within all the departments of the entire educational organization. An effective supervisory leadership must develop an articulated and co-ordinated program of study throughout the entire educational organisation. Influencing denotes an attempt to motivate teachers, students and other personnel concerned with education. For effective supervisory leadership supervisors should be able to communicate their ideas and intentions to the teachers clearly and precisely. A two way communication system is therefore necessary for both the supervisors and the supervised for exchange of opinions in order to enhance instructional effectiveness. Evaluation enables the supervisors to make decisions, which enable the educational process within an organization to be improved for an effective achievement of the pre-determ ined objectives.

Supervision aims at providing an independent assessment of the training institutes' strengths and weaknesses in order to inform educational stakeholders about the quality and standards of the training institutes and what needs to be done to improve them. Supervision is meant to bring forth quality assurance hence being a means of producing defect and fault free products in this regard standards are enforced through periodic inspection thus ensuring curriculum delivery given available educational resources with the subsequent good performance in training institutions.

\section{Supervision - Ministerial Level in Kenya}

The prime function of the directorate of Quality Assurance and Standards (QAS) and PTTOs is quality assurance, which encompasses effective monitoring of curriculum delivery in training institutions. Moreover, QAS and PTTOs should provide advisory services to learning institutions and other stakeholders on how to improve their training, encourage team playing that are influenced by a set of relationships: relationships within the college, between the college and the 
administrative level immediately above the college. Basic inputs factors such as the instructional equipment, training force and trainees are important variables that have bearing on success of training-learning activity. Product variablesare educational outputs and outcomes which are desired ends for having joined the college. The major task to be accomplished in the model is for educational planners to provide enabling climate in terms of supervision, instructional equipment and trainees with appropriate characteristics for effectiveness among TIVET colleges. As Charles Mutuku asserts in one of the daily media "there is need for proper regulation and elaborate supervision of the sector by the ministry concern, thus enhance the training quality". He further asserts that when you spend six months or whatever period required on a programme, it should show in a person that training really happened, it should be something companies like East African Breweries limited and Standard Chartered would appreciate (Daily Nation, 2005).

\section{Internal Environment - Institutional Level: The Principal and HoDs in TIVET Colleges}

Apart from allocating resources and monitoring and evaluation, MOST may delegate its authority to such lower power centres as head teachers, departmental heads and teachers. In this regard the Principal and heads of departments are identified as the first supervisors in the institute. The principal is a key player in the design and operations of the organizational arrangements of the institute. He or she is charged with the responsibility of steering the institute towards meeting its goals. As the one playing the managerial function at the institute level he is charged with the responsibility of providing enabling environment for an efficient and effective attainment of the organizational goals (Mbiti, 2007).

The principal coordinates all activities taking place in the institution. As such he should be knowledgeable in managerial skills, which enables him direct, plan, supervise, monitor, control, organize and make correct decisions regarding production in his institute. Due to their complexities, the production process in educational organization should be thoughtfully worked out for both effectiveness and efficiency by the principals assisted by HoDs. Teachers must teach subjects of their competence. Failure to do these amounts to gambling with the lives of students. Other members should also perform jobs for which they are qualified. The students who are themselves, the raw materials must not be ignored. All these would require a principal who is meticulous.

The principal ensures teachers prepare and develop appropriate instructional materials. Periodically checking learnt and evaluation materials of the students, visiting, observing and keeping a record of learning sessions in classrooms, laboratories, workshops etc. Moreover the principal is bestowed with the role of ensuring that discipline is cultivated, nurtured and maintained amongst the staff and students in the institute, hence a motivation of human resource in the institute. On this premises Kombo (1988) asserts that the basic reason why some institutions perform better than others in examinations is that while some principals organize learning for their students, others leave it to chance. Helinger et al (1995), noted that in many ways, the institutes principal is the most important and influential person in any training institute. It is his or her managerial skills that set the benchmark, direction, the tone and tempo of the institution, the climate of learning and the level of professionalism. His or her managerial skills are the fulcrum for the morale of the trainers and set the degree of concern for what trainees may or may not become. The principal should be held responsible for seeing that an appropriate learning environment is established and maintained (Campbell, 1983).

\section{Heads of Departments (HoD) in TIVET Colleges}

The HoD assists the principal in management of the institute, hence is responsible for departmental management and coordination (Mbiti, 2007). Being a middle level manager in the institute he or she is responsible for promoting efficiency in the teaching process in the institute with regard to syllabus grasp, schemes of work formulation, records of work maintenance and records of tests and examinations. The HOD also plays the role of supervising and carrying out internal inspection of subject teaching regularly.

\section{Teachers' Characteristics in Relation to Training Effectively in TIVET Colleges at the Classroom Level}

In planning the quality of education and training, it is clear that teachers are probably the most important components of the educative process, Anderson (1991) points out that there are, of course, other inputs such as information technology that entail digitalization of the curriculum and the development of e- content to training which affect learning outcomes, however it must be realized that any meaningful improvement in the quality of education that trainees receive is highly dependent on the quality of the instruction that teachers provide. Hence educational effectiveness could depend to a great extent on teacher effectiveness. Moreover, Kamotho minister for education in 1994 proclaimed, in education and 
training the importance of the teacher takes second position after that of the learner (Kombo, 1988). Hence teachers remain the most important resource for student instruction.

The teaching force becomes a particularly important factor in the education system since a qualified and motivated teaching force is a prerequisite for the promotion of higher achievement among learners (Kimalu, et al 2001). The quality of education and training could depend largely on the quality of teachers. The academic qualifications and professional training for the teachers are therefore key contributors of the quality of education and training. Kanori (2000) expressed the view that, "it is impossible to develop education in any country without ensuring regular supply of quality teachers". Shiundu (1982) noted that teachers without proper and adequate academic and professional qualifications fail to do justice to the subject they teach. Moreover, adequate qualification of the trainers instills self-confidence in the trainer and serves as an inspiration to the trainee. According to the Republic of Kenya (1976), the role and quality of teachers must be given the most critical consideration. The committee notes that the qualitative importance of education and training can only arise if there is improvement in the quality of teachers and teachers training. Kiragu (1978) observes that in the developing nations, teachers qualifications, amount of education and knowledge are positively related to trainees' achievements.

Sogomo (2000) stated that a country is as good as its education system and the education system is as good as its teachers. The quality of the teachers could therefore be critical to the performance in the education system. As such to become the best college in Kenya, in terms of offering quality career training, a college requires teachers who are professionals in their areas and in possession of high academic qualifications "High quality teaching requires the trainers have a deep knowledge of the subject matter for there is no substitute (United States education department 2000). The TIVET trainees must therefore be exposed to trainers who have the necessary academic qualifications and professional skills.

\section{Preparation, Presentation and Verbal Skills in the Classroom}

Teachers' attitudes, preparation, classroom practices and presentation have a strong bearing on trainees' performance (Republic of Kenya, 2003). Research conducted by Eshiwani (1985) reveals that the quality of education depends on the quality of its teaching force in that professional teachers have been trained on best methods of organizing and presenting subject matter to the learners. Good preparation is an ingredient of success in the teaching process (Rowland, 1992). Some people agree that presentation contributes at least $90 \%$ of all teachers' success rates. Good preparation will give a teacher confidence that allows him or her to carry out his or her duties effectively. A trainer should aim at preparing a meaningful sequence of learning activities. Controlling trainees is made easier by a carefully prepared teaching and learning methods.

Being able to explain clearly, asking probing questions and leading trainees on to solution are all relevant interpersonal skills which are needed for success. In a survey of learners, one of the main reasons for assessment of a "bad teacher" was inability to explain the subject well (Rowland, 1992). It is interesting to note that the willingness of learners is eroded because of poor presentation and communication methods.

\section{Continuous Assessment as Part of Teacher's Preparation for the Specific Class}

Assessment is considered to be not just a means of obtaining information about education and training but also a lever of reform (Madues and Kellaghan, 1991; Pophan, 1997). Thus assessment is ascribed an active role, one in which it is consciously used in the educational and training process to change teacher behaviour and classroom instruction which in turn is expected to raise the standards of students learning. Moreov er, in the right hands, assessment inspires, motivates and provides feedback which is essential for targeting prompt corrective help (Petty, 2001).

Assessment in education and training is the process of obtaining information that is used to make education decisions about students, to give feedback to the student about his or her progress, strengths and weaknesses, to judge instructional effectiveness and curricular adequacy and to inform policy (AFT, NCME, NEA, 1990). Thus student regular assessment by teachers could be a powerful learning tool which could be used with great advantage in the teaching learning process. In most circumstances, the only way of finding out whether teaching has been successful is by measuring, or at least identifying the effect it has on the learners, if it has not had the intended effect then the teacher should look back over the method used and what went wrong and on the basis of assessment should know what the learner needs to further progress (Hendrikz, 1994).

Assessment in education may take many forms, such as formal written exercises, tests, examinations, practical, 
out of class assignments among others. According to studies carried out by Shiefelbein and Simmons (1981) on determinants of school achievements it is shown that there is a close relationship between the out of class academic assignments and achievements. Moreover, in his study about factors that influence performance in schools in Western Province, Eshiwani (1983) concurs with this view that assignment influence academic performances of learners. He established that over $60 \%$ of the schools studied had no formal homework assignments given to students and that where it was administered there was no serious follow up by either the teachers or head teachers. Consequently, students ended up underachieving.

\section{Educational Facilities Provision in TIVET Colleges}

Good infrastructure and regular access to teaching and learning facilities are essential features in a sound and vibrant TIVET system (TIVET Audit, 2003). As such an institution requires physical facilities, such include land, school buildings, play ground; school equipment, includes text books, stationery, teacher guides and reference materials and other essential teaching aids. Inadequacies in school equipment could constitute one of the most important adverse. Text books, as inputs in education play a crucial role in the determination of educational outputs and outcomes. Availability of text books remain the most crucial item required for a given standard of education, (Kimalu, 2001). According to the recommendations of the presidential working party on education and manpower training for the next decade and beyond (Republic of Kenya, 1988) TIVET should be provided with adequate scientific facilities, equipment and materials for effective training. Further, Eshiwani (1983), looking at factors affecting performance in Western Kenya stated that schools that were found to have good facilities were performing well academically. As such the availability of facilities distinguishes between high and low achievement among training institutions.

\section{Students' Characteristics in Relation to Learning Readily in TIVET Colleges}

Trainees' characteristics are be defined to encompass variables that describe motivation, self- efficacy, self regulation and discipline, and achievement of goals and study habits. The motivated behaviour of a person does not move in a haphazard way but is directed towards a selected goal. For example a student who is motivated to secure high marks in an examination concentrates on his studies by selecting appropriate means to reach his/her goal (Ingule, 1996).

In education, self-efficacy is seen to be related with effort, persistence and achievement. Ergul (2004) stated that individuals who have high sense of self- efficacy for accomplishing a task work harder and persist longer when they encounter difficulties, whereas those who do not feel efficacious may quit or avoid a task. Self- efficacy beliefs motivate trainees and make them form beliefs about what they can do, set goals for themselves and plan courses of action designed to realize what they can do to achieve valued fortunes.

In academic contexts, high academic achievement will also require self-regulation. Self regulation refers to processes that involve the activation and maintenance of cognitions, behaviours and effects which are systematically oriented towards the attainment of goals (Schunk, 1989). Self-regulation entails learning style for students comprising of strong abilities like setting goals for developing knowledge, and choosing strategies that yield academic achievement. Ergul (2004) states that self-regulated learners set academic goals, select appropriate learning strategies to achieve these goals. Student's choice ensures self-involvement in the learning task and the students will be highly motivated by following their own interests and curiosity. Moreover, goals are important cognitive process effecting student motivation (Bandura, 1997). Achievement goals exert great pressure on students to take studies enthusiastically and propel a student to have greater self-efficacy and self-regulation. Since learning is more personal and responsibility more on the shoulders of students in tertiary level education in comparison to lower level education, motivational constructs are more important. TIVET student must have strong drive in being successful at what they do. Their interests influencing these motives stimulate them to engage in behaviours that are designed to fulfil these motives. The personality variables of self-efficiency and goal commitment should influence their task performance. These make them exert greater efforts in their studies because they believe they will succeed.

\section{Discipline and Its Bearing on the Success of the Learning Activity in TIVET Colleges}

Discipline is a very crucial factor in determining academic achievements. Docking (1989) views discipline as a significant aspect that is essential in an orderly system that creates the conditions in which learning takes place, and that allows the aims and objectives of the school to be achieved. In a learning institution, discipline helps trainees to perform the 
activities necessary for enhancing their training and at the same period limiting those behaviours that are self destroying. If a school has disciplinary problems then it's likely that its academic results will be affected negatively simply because student's commitment to their academic work is futile.

Indiscipline damages morale, influences the training and produces an atmosphere which is discouraging to staff and trainees. Further, teachers seek to avoid interacting with rude students. The exercise of discipline should be a habit in the training institute for without discipline it becomes much more difficult to achieve (Rowland, 1992). The way discipline is maintained is a very essential educational element for the development of a healthy and dynamic training institution. Indiscipline breeds unrest and disturbance that culminate to closure of colleges. These subsequently interfere with the students learning time hence impacting negatively on syllabus coverage a recipe for poor performance.

Educational supervision entails getting things right and this done by exalting personnel to do better ,work harder and advising on best tools and techniques to use, analyse and drive out performance problems. Moreover, the effectiveness of TIVET depends on many other factors, for example, how well the trainees are prepared. The process of preparation is further affected by among others the facilities available in the institution, teachers and students characteristics, where the training is taking place. The study examined these education inputs identified as being significant in influencing performance and tested their impact on TIVET effectiveness.

\section{Research Methodology}

Descriptive survey design was adopted in conducting this study. Descriptive survey involves collecting information by administering a questionnaire or interviewing to a sample of individuals. The design was appropriate as it allowed describing, recording, analyzing and reporting conditions that exist or existed. The design yields data, useful in evaluating present practices and providing basis for decision. The design also generated both numerical and descriptive data utilizable in measuring correlation coefficient between variables influencing colleges' performance. Data collection was done through the distribution of questionnaires.

Quantitative and qualitative methods were used for data analysis. Quantitative data was analyzed using a computer programme, the Statistical Package of Social Sciences (SPSS). The results from the data analysis was presented using frequency distribution, percentages, tables, bars charts and measures of central tendency. Frequencies were converted to percentage so that they were easier to interpret, analyze the data and present the findings of the research. Qualitative data that was generated from open-ended questions was organized into themes, categories and patterns pertinent to the study. From this, the researcher closely evaluated the usefulness of information in answering research questions.

\section{Data Analysis, Presentation and Discussions}

Data was sought from 2 PTTOs, 8 principals, 20 Heads of Department (HoDs), 40 trainers and 320 trainees. However, one principal did not fully complete the questionnaire and was thus excluded from the analysis, meaning thatdata nalysis is based on responses from seven principals. The demographic data of the respondents is presented below. One of the characteristics of the sample was on the academic qualifications of PTTOs. None had attained a master's degree and in the professional grade, the PTTOs were at job group M, a grade far much lower than most of the principals and H.O.D whom majority (71.4 \%) were in job group $\mathrm{N}$ and one principal having Master of Science and in job group Q. The level of academics the PTTO had and job group were considered in an attempt to assess control one had over those he or she oversees.

The PTTOs response indicated that the number of supervisors and supervision of TIVET colleges were not adequate. They felt that there was understaffing of TIVET supervisors hence inadequate supervision in the region. Both PTTOs indicated the inadequacy of supervision personnel and ministry involvement in supervision of TIVET.

The findings further point out that the PTTOs were inadequately equipped to supervise TIVET given their academic qualification and job group s compared with Principals (71.4\%), H.O.D(20\%) teachers (2.5\%) were above job group M where PTTOs were placed. The PTTOS also pointed out that the supervision roles were not well spelt out Kimemia (1989) notes that supervisors in the education system are plagued by ambiguities where their positions and roles are ill-defined and there is lack of agreement on their functions. Indeed the PTTOs commented that colleges' visits are mostly when there are B.O.G. meetings this denies their opportunity to interact with other members of the training institutions. Lack of supervision schedule further aggravates the situation.

The PTTOs were of the opinion that supervision activities should be intensified by principals and H.O.Ds if 
effectiveness in TIVET is to be improved. They noted there was need to have frequent meetings between with relevant educational stakeholders (PTTOs, ministry officials, principals, H.O.D and trainers). Some information was gathered from an observation schedule to supplement the information collected in the questionnaire. The researcher visited both PTTOS offices observed the following. There were established offices for PTTOs headed by them and no other personal apart from a secretary which is shared with other provincial officers. There were no work programmes apart from a diary indicating B.O.G meetings in various colleges, no supervision manuals and inspection books.

The findings therefore indicate that the provision of staff and personals is mandatory if effectiveness is to be realised in TIVET. There is a need for proper staffing with TIVET supervisors in these regions. They also commented that supervision of TTIs have a strong effect on training, however TIVET colleges have had low supervision and this could be a factor contributing to poor management in these colleges thus leading to their ineffectiveness.

The TIVET trainer's skills and knowledge were presented as inadequate by the PTTOs especially in engineering courses. Any meaningful improvement in the quality of training and education that trainees receive is highly dependent on the quality of the instruction that trainers provide. This is in turn dependent on the trainer's academic and professional qualifications (Shiundu, 1982; R.0.K, 1976).

With a big proportion of trainers being of less than degree qualification, One PTTO posed how does a diploma holder a diploma. This concurs with Charles Mutuku (Daily Nation, 2005), who comments that, to become the best college in Kenya, in terms of offering quality career training, a college requires trainers who are professionals in their areas and in possession of a least a degree moreover, it true that trainees can learn more if their trainers knew more in their areas of specialization. With this effectiveness can be realized among the middle level TIVET colleges.

The study further sought to find out the possible measures that could be put in place in an attempt to ensure effectiveness of TIVET. The PTTOs responses indicated that improving supervision, supervisory facilities and functions such as provision of adequate human resource, proper means of transport, well defined supervisory roles and recruitment of highly qualified staff academically and highly ranked (job groups) staff in supervisory positions ranked highest. Other measures proposed by these respondents included motivation of supervisors ,trainers, increased commitment by Principals to their work, further training of trainers and provision of adequate training and learning materials in TIVET colleges.

On the teaching and learning resources both PTTOs agreed that they were there but most were obsolete and require replacement with modern ones to facilitate effective training hence improvement in performance among middle level TIVET colleges . To improve performance in TIVET institutions, the PTTO suggested the following:

- Recruitment of principals with high academic and professional qualification and PTTOs and principals to be placed in job groups above the H.O.Ds and trainers in order for them to execute authority without fear (....) the PTTOs are holders of no more than Bachelors Certificates, some college Principals too are only holders of diplomas. Some HoDs have minimal qualifications; such qualifications bring frustrations to them and eve teachers who are sometimes of higher qualifications hence ineffectiveness among TIVET colleges.

- Creational of centres of excellence

- The government to recruit TIVET trainers with qualifications above diploma level. These enhance subjectmastery. Subject Mastery contributes to better teaching stemming from the trainer's adequate understanding of topics in hand (Hustler and Me Intyre (1996).

- Regular and elaborate supervision of middle level TIVET colleges to be introduced to check on how the members are performing progressing and communicating to them on a personal as well as an official level.

- Constant sullabi review.

- Just as note by Kimani (1983) unfavourable attitude to wards technical education continues to be a contributing factor to performance to TIVET colleges. The PTTOs reported that there are instances where trainees are forced to a course by parents and this does not augur well to effectiveness among TIVET colleges.

Out of the seven principals who participated in the study, 1(14.3\%) had a Master of Science degree in Technology, 4 (57.1\%) had Bachelor of Education qualifications while $2(28.6 \%)$ had Diploma qualifications. Table shows the number of years they had served in their current institutions.

Table 4.1: Number of years of service in principalship

\begin{tabular}{ccc}
\hline Period of service & Frequency & Percent \\
\hline 4 years & 2 & 28.6 \\
& & \\
& 252 &
\end{tabular}




\begin{tabular}{ccc}
3 years & 1 & 14.3 \\
5 years & 1 & 14.3 \\
2 years & 3 & 42.9 \\
\hline Total & 7 & 100.0 \\
\hline
\end{tabular}

Table 4.1 above shows that $3(42.9 \%)$ principals had served in their current institutions for two years, 2 (28.6\%) for four years while one (14.3\%) principal had served for 3 years and another for 5 years. Four (57.1\%) of the principals were in Job Group N, 2 (28.6\%) were in Job Group M while 1 (14.3\%) was on Job Group Q.

Four (57.1\%) of the TTIs visited had had six departments each, 1 (14.3\%) had five departments, 1 (14.3\%) seven departments while another 1 (14.3\%) had eight departments. Table 4.2 shows the various departments that were headed by the $20 \mathrm{HoDs}$ who participated in the study.

\begin{tabular}{|c|c|c|}
\hline Department & Frequency & Percent \\
\hline Clothing & 4 & 20.0 \\
\hline Business & 2 & 10.0 \\
\hline Building and Civil Engineering & 3 & 15.0 \\
\hline Automotive & 4 & 20.0 \\
\hline Electrical & 5 & 25.0 \\
\hline Food and Beverage & 1 & 5.0 \\
\hline Applied Science & 1 & 5.0 \\
\hline Total & 20 & 100.0 \\
\hline
\end{tabular}

As shown in Table 4.2, out of the 20 HoDs who participated in the study, 5 (25\%) were from Electrical Department, 4 (20\%) were from Clothing Department, another 4 (20\%) from Automotive Department while $3(15 \%)$ were from Building and Civil Engineering. Other departments included Business, Food and Beverage, and Applied Sciences. Figure 4.1 indicates the highest academic qualifications attained by HoDs.

Figure 4.1 HoDs' highest academic qualifications

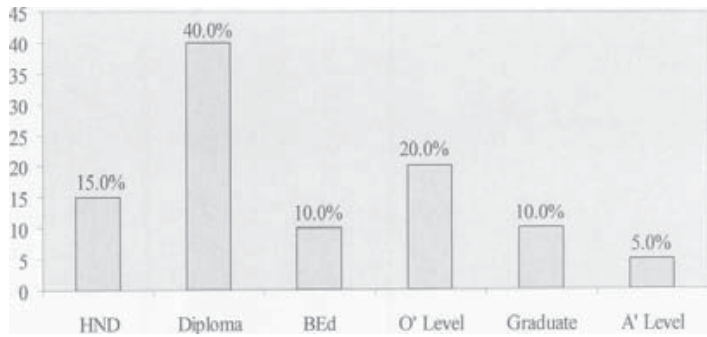

\section{Academic Qualifications}

Eight (40\%) HoDs had diploma qualifications, 4 (20\%) had 'O' Level, 3 (15\%) had Higher National Diploma qualifications, while $2(10 \%)$ had Bachelor of Education qualifications. Twelve (60\%) of the HoDs were Job Group M, $4(20 \%)$ were in job Group L while another 4 (20\%) were in Job Group N.

In order to ensure efficient supervisory services the ministry and the administration must select highly qualified and competent supervisors. PTTOs, principals and $\mathrm{HoD}$ must be people with high academic and professional qualifications plus job group ranks and experience of their work, otherwise it will continue to be difficult for their subordinates to respect them (Mbiti, 2007). Without respect from subordinates it becomes futile to exercise power in a learning institution and this is detrimental to effectiveness in the particular training institution. The above poor supervisors' qualities have contributed to TIVET colleges' ineffectiveness.

Forty trainers took part in the study. Twelve (30\%) of the trainers were from Electrical department, 10 (25\%) were from Automotive Department, 6 (15\%) were in Business Studies, 4 (10\%) were in Food and Beverage while another 4 $(10 \%)$ were from Building and Civil Engineering Department. Table 4.3 shows the highest academic qualifications attained by trainers. 


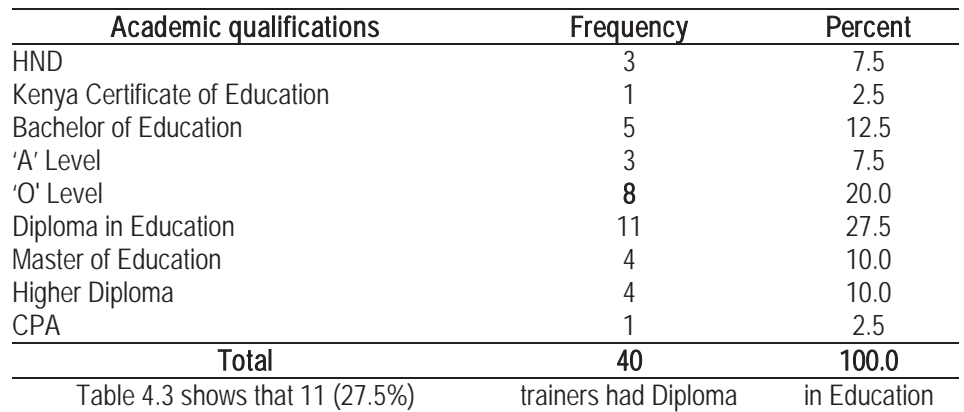

(20\%) had 'O' Level qualifications, 5 (12.5\%) had bachelor of Education qualifications, 4 (10\%) had Master of Education while $4(10 \%)$ had Higher Diplomas. Eighteen (45\%) of the trainers were in Job Group L, 17 (42.5\%) were in Job Group M, 4 (10\%) in Job Group K while 1 (2.5\%) in Job Group N.

The quality of the trainer is critical to the performance in the education system (Daily Nation, 2005; Shiundu, 1982; Kombo, 1988) among others. Excessive deployment of poorly qualified trainers (diploma holders) and lowly graded to teach TIVET students as indicated in the responses will perpetually make the trainees under perform in national examinations.

Out of the 320 trainees who participated in the study, 307 (95.9\%) were boarders while 13 (4.1\%) were day scholars. This makes majority trainees to have ample to have self- regulated studies beneficial for success (Ingule, 1996).

\section{Past National Examinations Results Obtained by Technical Training Colleges}

The first study objective was to find out type of past results the colleges have obtained in national examinations for the period ranging 2002-2006. Data on national examinations results for the period 2002- 2006 were available. Table 4.4 shows the percentage of students who got passes and percentage of students who got fails in the national examinations in the period 2002-2006.

Table 4.4: Analysis of technical examinations results year 2002 - 2006

\begin{tabular}{|c|c|c|}
\hline Year & Pass\% & Fail \% \\
2002 & 35.6 & 64.4 \\
2003 & 41.0 & 59.0 \\
2004 & 47.4 & 52.6 \\
2005 & 44.4 & 55.6 \\
2006 & 55.6 & 44.4 \\
\hline
\end{tabular}

The table above shows that there has been mixed performances in national examination performance for the eight visited TTIs for the study period (2002- 2006) in terms of percentage of students who registered passes. The percentage pass late has steadily remained below $50 \%$ pass with only $55.5 \%$ pass being recorded 2006 . Table 4.5 shows how the respondents (principals, HoDs, trainers and trainees) rated the performance of their colleges in national examinations for the period 2002 - 2006.

Table 4.5: Ratings of performance in KNEC exams

\begin{tabular}{lcccc}
\hline \multirow{2}{*}{ Respondents } & \multicolumn{4}{c}{ Ratings of performance in KNEC exams } \\
\cline { 2 - 5 } & Excellent & Good & Average & Poor \\
\hline Principals $(\mathrm{N}=7)$ & - & $28.6 \%$ & $71.4 \%$ & - \\
HoDs $(\mathrm{N}=20)$ & $15.0 \%$ & $40.0 \%$ & $35.0 \%$ & $10.0 \%$ \\
Trainers $(\mathrm{N}=40)$ & $5.0 \%$ & $55.0 \%$ & $32.5 \%$ & $7.5 \%$ \\
Trainees $(\mathrm{N}=320)$ & - & $13.8 \%$ & $54.1 \%$ & $32.1 \%$ \\
\hline
\end{tabular}


Form Table 4.5 it can be seen that $5(71.4 \%)$ of the principals rated the performance of their students for the last five years as average while $2(28.6 \%)$ rated the performance as good. Eight (40\%) HoDs rated the performance of the trainees as good, $7(35 \%)$ as average, $3(15 \%)$ as excellent while $2(10 \%)$ rated the trainees' performance as poor. Of the forty trainers, $22(55 \%)$ rated the academic performance as good, $13(32.5 \%)$ average while $3(7.5 \%)$ excellent. A total of $173(54.1 \%)$ trainees rated the performance of their colleges in past KNEC examinations as average, 103 (32.1\%) rated the performance as poor while $44(13.8 \%)$ rated it as good. The rating on the performance by the respondents clearly indicate that TIVET Colleges require to be more aggressive in their production function in order to in the pass rate for the enrolled trainees hence their effectiveness be positively perceived in the line of producing the required labour force for the nation.

\section{Institutional Factors Affecting Middle Level Colleges' Academic Performance}

The second study objective was to identify the specific institutional factors affecting middle level colleges' academic performance. The principals, HoDs, trainers and trainees were presented with various institutional factors that could have negative influence on their institute's performance in public examinations. They were to indicate the factors that they felt had a significant negative influence on performance. Their responses are shown in Table 4.6

Table 4.6: Degree of negative influence of institutional factors on performance

\begin{tabular}{|l|c|c|c|c|}
\hline \multirow{2}{*}{ Factors } & \multicolumn{3}{c|}{ Percentage responding significant } \\
\cline { 2 - 6 } & $\begin{array}{c}\text { Principals } \\
(\mathrm{N}=7)\end{array}$ & $\begin{array}{c}\text { HoDs } \\
(\mathrm{N}=20)\end{array}$ & $\begin{array}{c}\text { Trainers } \\
(\mathrm{N}=40)\end{array}$ & $\begin{array}{c}\text { Trainees } \\
(\mathrm{N}=320)\end{array}$ \\
\hline Students indiscipline & 42.9 & 45.0 & 75.0 & 42.8 \\
Students low self motivation & 57.2 & 60.0 & 75.0 & 53.8 \\
Student's poor study techniques & 57.1 & 80.0 & 80.0 & 71.5 \\
Student's low self-efficacy & 57.2 & 70.0 & 70.0 & 71.9 \\
HoDs inability to oversee what happens in departments/classes & 85.7 & 45.0 & 60.0 & - \\
Inadequacy of textbooks and training materials & 42.9 & 70.0 & 60.0 & 79.4 \\
Inadequate training of teachers & 14.3 & 50.0 & 60.0 & - \\
Frequent lateness to class & 57.1 & 50.0 & 57.5 & 66.9 \\
Poor teacher preparation & 71.4 & 45.0 & 60.0 & 18.5 \\
Poor teacher presentation & 71.4 & 50.0 & 57.5 & 24.1 \\
\hline
\end{tabular}

Majority of the Principals reported that the following factors were significant in influencing performance negatively as portrayed by table 4.6 as; HoDs inability to oversee what happens in departments/classes, poor teacher preparation, poor teacher presentation, student's low self-efficacy, students low self-motivation and student's poor study techniques as the factors contributing to ineffectiveness among TIVET colleges in central and Eastern provinces in order of priority.

Similarly most of the HoDs reported the following factors as significant in negatively influencing performance as depicted in table 4.6 as follows students' poor study techniques, students' low self-efficacy, inadequacy of textbooks and training materials, students' low self-motivation, inadequate training of teachers, frequent lateness to class, poor teacher presentation in order of serious contribution.

Further most of the trainers reported that the following factors were critically significant in undermining effectiveness among TIVET Colleges, student's poor study techniques, students' indiscipline, students low selfmotivation, student's low self-efficacy, HoDs inability to oversee what happens in departments/classes, inadequacy of textbooks and training materials, inadequate training of teachers and poor teacher preparation.

Results shown in Table 4.6 further indicate that the following factors, as reported by the trainees, were significant in negatively influencing performance. The percentages indicate the number of trainees who participated in the study and agreed to that effect; student's low self-motivation (53.8\%), student's poor study techniques (71.5\%), student's low selfefficacy (71.9\%), inadequacy of textbooks and training materials (79.4\%) and frequent lateness to class (66.9\%).

The principals were asked to give the main reasons which they considered to have negative influence in their institutes' performance in public examinations. They gave the following reasons:

- Lack of enough training materials

- Some lecturers lack commitment

- Limited inspection from the ministry in curriculum development

- Inadequate monitoring and evaluation 
The HoDs gave the following factors as having negative influence on performance in the institutes:

- Students poor attitude to certain subjects

- Inadequate facilities in the library and laboratory

- Teachers lack commitment

- Lack of exposure to both trainers and trainees

- Inadequate syllabus coverage

When asked to give the main factors that had negative influence on their institutes' performance, the trainers gave the following:

- Poor reading culture among students

- Lack of commitment by both teachers and students

- Poor time management

- Absenteeism due to lack of fees

- Low self-motivation

The trainees gave the following factors as contributing negatively to their institutes' performance in public examinations: -

- Lack of adequate facilities for practical lessons

- Few teaching/reading materials

- Failure to attend classes

- Poor time management

- Poor self-motivation

- Poor discipline

- Reluctant teachers

- Bad administration policies from the institution

These findings indicate that there are many institutional factors that, lead to poor performance of TTIs. These include teacher-related factors like ill prepared and trained teachers (teachers with low qualification), lack of morale and inadequacy of teachers, student-related factors like indiscipline and lack of motivation, and self-efficacy. This is in line with findings from previous studies, which have shown that academic performance is affected by a number of factors, including student-related factors like indiscipline. The exercise of discipline should be a habit in the training institute for without discipline it becomes much more difficult to achieve (Rowland, 1992;Docking, 1989) and willingness to learn and self-regulation (Kovach,2000;Butler and Winnie, 1995),self-efficacy (Bandura, 1997), school-related factors like adequacy of resources and facilities, textbooks and teaching materials (C)wuor,2003;RoK,1988; Eshiwani, 1993); teacher-related factors like teachers educational qualifications (Shiundu, 1982) teacher morale, teaching methods ( RoK, 2003;Farrat, 1980). Farrat (1980) denotes that some bad methods used and poor presentation by teachers actually cause learning blocks for their learners a factor that was noted to be contributing to ineffectiveness among middle level TIVET colleges and poor preparation (Rowland, 1992); and ministerial and institute administrators' traits (Kombo,1988; Helinger et al,1995;Mbiti,2007; Hopkins et al 1997) among others.

Observations made in eight of the technical training institutes indicated that equipment were available in $6(75 \%)$ institutions but in $4(50 \%)$ of them it was inadequate. Textbooks were inadequate in $7(87.5 \%)$ institutions whereas in 1 (12.5\%) TTI, they were not available. Students study schedule and CAT timetables were not available in all the $8(100 \%)$ TTIs whereas supervision schedule was available in only $1(12.5 \%)$ TTI. Staff meetings were being held in all the 8 $(100 \%)$ institutions at the beginning and end of the academic term. However, these were inadequate in $50 \%$ of the institutions. Classrooms and laboratories were there in all the TTIs though grossly inadequate and with obsolete facilities in $6(75 \%)$ of the middle level colleges visited. HoD offices and library access were not available in $50 \%$ of the institutions. This denied the HoDs the opportunity to hold effective consultation with their teachers a factor contributing to TIVET colleges' ineffectiveness.

\section{Physical and Human Resource and Supervisory Factors Affecting Academic Performance}

The third study objective was to establish the relationship between the availability of physical and training resources, supervision, teachers' characteristics, and students' characteristics and the trainees' academic performance.The principals were asked to state how regularly the ministry officials visited their institutions. Table 4.7 presents their responses. 
Tale 4.7: Rate of ministry officials' visit to institutions: Principals' responses

\begin{tabular}{lcc}
\hline \multicolumn{1}{c}{ Frequency of visits } & Frequency & Percent \\
\hline Once a year & 2 & 28.6 \\
Once a term & 3 & 42.9 \\
More than twice a term & 2 & 28.6 \\
\hline \multicolumn{1}{r}{ Total } & 7 & 100.0 \\
\hline
\end{tabular}

Three (42.9\%) principals reported that the ministry officials visited their institutions once a term, 2 (28.6\%) once a year and another 2 (28.6\%) reported that the officials visited more than twice a term. All the $7(100 \%)$ principals agreed that the standard of inspection and supervision of TIVET institutes were low in Eastern and Central region. Secondly, the supervisors available were not adequately trained to do inspection and supervision of TIVET colleges. The training they received when they were being trained to become teachers was not adequate on supervision of technical training colleges.

Three (42.9\%) of the principals reported that they visited classes to supervise their teachers while conducting instructional activities while 4 (57.1\%) reported they never visited classes for supervision. Figure 4.2 shows how often principals checked teachers' lesson plans, scheme of work and students records.

Figure 4.2: Rate at which principals check professional documents

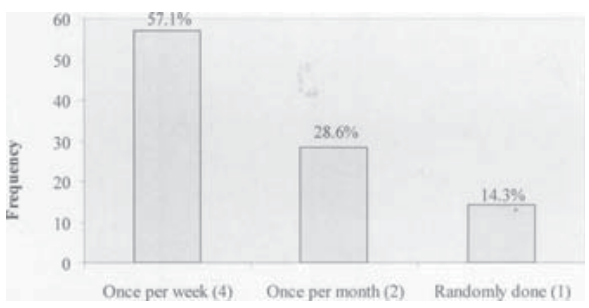

\section{How often}

As shown in Figure 4.2, 4 (57.1\%) principals checked the professional documents once per term, 2 (28.6\%) checked them once per month, while $1(14.3 \%)$ reported that it was randomly done. Five (71.4\%) principals reported that CATs were done twice per week while $2(28.6 \%)$ reported that CATs were done thrice a week.

Further, $5(71.4 \%)$ of the principals reported that teachers were to a very large extent assigned subjects that they did not study for in college, $1(14.3 \%)$ reported that this happened to a large extent while another $1(14.3 \%)$ reported this never happened in his institute. Trainers qualifications, amount of education and knowledge are positively related to students achievements( Kiragu,1978; Kimalu et al,2001;:Daily Nation,2005).This phenomenon of trainers being assigned to teach subjects and levels they themselves never went beyond before their employment have greatly contributed to ineffectiveness among the middle level TIVET colleges.

Shiundu (1982) states that teachers assigned subjects they did not study for in college do a lot of disservice to the subject and their learners. This is a factor that could be contributing significantly to ineffectiveness among TIVET. He noted that teachers without proper and adequate academic and professional qualifications fail to do justice to the subject they teach. In addition, he postulates that adequate qualification of the trainer instils self-confidence in the trainer and serves as inspiration to the trainee.

All the $20(100 \%)$ HoDs reported that they monitored teachers work through supervision and evaluation. Asked to state how they ensured schemes of work, lesson plans and notes were developed and used in the course of teaching, they stated as follows: -

- Through supervision and evaluation

- Making weekly records

- Adequate implementation of policies

- Check-ups at the beginning of the term

- Preparation for scheme of work plus remarks column 
- Prompt submission of reports

- Discussion with teachers

Seventeen (85\%) HoDs commented that students' motivational level for self directed studies and completion of out of class assignments were unsatisfactory. All the $40(100 \%)$ trainers reported that they gave assignments to their students. Twenty six (65\%) of the trainers reported that more than 50 percent of the students completed assignments, 9 (22.5\%) reported that 50 percent of the students completed assignments, while 5 (12.5\%) reported that all (100 Percent) of the students of the students completed assignments. Asked to comment on promptness of handing back corrected assignments and CATs, 11 (27.5\%) trainers reported that they returned them very promptly, 23 (57.5\%) promptly, and 6 (15\%) not promptly.

Twenty eight (70\%) trainers reported that they were not allocated to teach subjects they never covered in college, while $12(30 \%)$ were allocated such subjects. The trainers were asked to indicate the rate at which principals performed various activities related to supervision. Their responses are summarized in Table 4.8

Table 4.8: Rate of principals performing various supervisory activities: Trainers' responses

\begin{tabular}{|l|c|c|c|c|c|c|c|c|}
\hline \multicolumn{1}{|c|}{ Activities } & \multicolumn{2}{c|}{$\mathrm{VO}$} & \multicolumn{2}{c|}{$\mathrm{O}$} & \multicolumn{2}{c|}{$\mathrm{N}$} \\
\cline { 2 - 8 } & $\mathrm{F}$ & $\%$ & $\mathrm{~F}$ & $\%$ & $\mathrm{~F}$ & $\%$ & $\mathrm{~F}$ & $\%$ \\
\hline Visits classes to supervise instructional activity & 1 & 2.5 & 10 & 25.0 & 20 & 50.0 & 9 & 22.5 \\
\hline Checks on evaluation procedures used to assess the students academic achievement & 0 & 0.0 & 29 & 72.5 & 8 & 20.0 & 3 & 7.5 \\
\hline Checks on students work & 0 & 0.0 & 5 & 12.5 & 25 & 62.5 & 10 & 25.0 \\
\hline Gives clear direction on what to be done & 9 & 22.5 & 23 & 57.5 & 7 & 17.5 & 1 & 2.5 \\
\hline Provides adequate teaching and training materials on time & 11 & 27.5 & 27 & 67.5 & 2 & 5.0 & 0 & 0.0 \\
\hline Stresses on the achievement of academic goals and encourages students to study & 19 & 47.5 & 20 & 50.0 & 1 & 2.5 & 0 & 0.0 \\
\hline
\end{tabular}

Key: VO : Very Often O: Often R: Rarely N: Never

The results presented in Table 4.8 show that according to trainers, most principals often performed the following activities:

- Giving clear direction on what is to be done (80\%)

- Providing adequate teaching and training materials on time (95\%),

- Stressing on the achievement of academic goals and encourages students to study (97.5\%).

- On the other hand, principals rarely or never performed the following: -

- Visiting classes to supervise instructional activity (72.5\%)

- Checking on students work (90\%)

It is correct to note that, principals committed to their work are responsible, have sound moral standing and are available for teachers and trainees (Owour,2003). These are ingredients for excellence in work performance and when they are lacking in TIVET colleges effectiveness becomes elusive as portrayed in their past performance. The trainers were asked to indicate the rate at which HoDs performed various activities related to supervision. Their responses are summarized in Table 4.9

Table 4.9: Rate of HoDs performing various supervisory activities: Trainers' responses

\begin{tabular}{|l|c|c|c|c|c|c|c|c|c|}
\hline \multirow{2}{*}{\multicolumn{1}{|c|}{ Activities }} & \multicolumn{2}{c|}{ VO } & \multicolumn{2}{c|}{ O } & \multicolumn{2}{c|}{ R } & \multicolumn{2}{c|}{ N } \\
\cline { 2 - 10 } & F & $\%$ & F & $\%$ & F & $\%$ & F & $\%$ \\
\hline Supervises your teaching & 15 & 37.5 & 11 & 27.5 & 5 & 12.5 & 9 & 22.5 \\
\hline Checks on training instruments you've prepared & 3 & 7.5 & 26 & 65.0 & 8 & 20.0 & 3 & 7.5 \\
\hline Scrutinizes what you've covered in class & 3 & 7.5 & 19 & 47.5 & 7 & 17.5 & 11 & 27.5 \\
\hline Checks your formative assessments & 4 & 10.0 & 23 & 57.5 & 10 & 25.0 & 3 & 7.5 \\
\hline Monitors trainees activities & 10 & 25.0 & 24 & 60.0 & 6 & 15.0 & 0 & 0.0 \\
\hline
\end{tabular}

Key: Vo: Very Often O: Often R: Rarely N: Never

Results in Table 4.9 show that, as reported by trainers, most of the HoDs often supervised the trainers' teaching (65\%), and monitored trainees' activities (85\%). These have contributed to the marginal improvement in performance among various middle level TIVET colleges in Central and Eastern provinces, in agreement to the assertion that " participants in any enterprise respond favourably to control, guidance and direction"...one important measure of the HoDs worth was 
therefore the extent he or she was able to create an atmosphere of mutual confidence within which each trainer and trainee was challenged and encouraged to put more efforts towards the realisation of the institutions goal of achieving better academic performance. However, a significant proportion of HoDs (45\%) rarely or never scrutinized what trainers have covered in class. This low level of supervision (55\%) jeopardises effectiveness among TIVET colleges for supervision is one of the basic requirements in administration aimed at maintaining the efforts of training personnel in line with the goals of the administration (Lane, et al 1966). Eleven (27.5\%) trainers reported that supervision affects their performance in class. This is in agreement with Mbiti (2007) assertion that supervision is meant to promote educational efficiency.

When supervisors perform their duties well there is bound to be remarkable efficiency in the work carried out by their subordinates. Twenty-seven (67.5\%) trainers reported that trainees showed high motivational level for learning, in that majority were admitted with very low marks but they improved with time. They also reported that the class attendance was good and that class debates and discussions were enhanced. Despite the low achievement levels in TIVET colleges the assertion by trainers regarding high motivational levels for learning concurs with Ingule (1996)and (Ergul,2004) who note that students who are motivated to secure high marks in examinations concentrate on their studies by selecting appropriate strategies to enable them reach their goals.

Figure 4.3 shows the rate at which trainees missed classes. Ninety $(28.1 \%)$ of the trainees reported that they missed classes rarely, while $23(7.2 \%)$ missed class a lot. 207 (64.7\%) trainees never missed classes an indication of commitment required for success in academic field.

Figure 4.3: Rate at which students missed classes

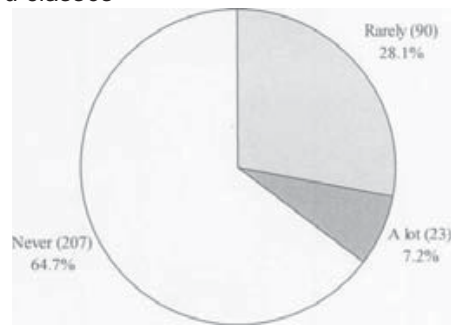

The trainees were asked how much time they spent during revision while at home or after classes per week, to which 114 (35.6\%) reported that they revised for many hours while 206 (64.4\%) reported that they revised for few hours, a factor showing low self-drive. Self-directed learning gives control and responsibility for learning to the trainee. Its curiosity, encourages students to take responsibility for their own development and learning, and promotes personal and academic growth (Carl, 1994). With limited time allocated to individualized and own study, it makes it quite difficult for middle level TIVET trainees to perform excellently in their examinations.

A total of $223(69.7 \%)$ of the students reported that they sat for their Continuous Assessment Tests (CATs) twice a term. Eighty-three (83\%) trainees reported that they were never given home assignments. Of those who sat for CATs and did assignments, 175 (54.7\%) trainees reported that teachers gave them feedback after correction promptly, 102 (31.9\%) very promptly while $43(13.4 \%)$ reported not promptly. This is captured in Table 4.10.

Table 4.10: Rate of teachers giving feedback after correction of CATs and assignments: Students' responses

\begin{tabular}{|c|c|c|}
\hline Rat of giving feedback & Frequency & Percent \\
\hline Very promptly & 102 & 31.9 \\
\hline Promptly & 175 & 54.7 \\
\hline Not promptly & 43 & 13.4 \\
\hline Total & 320 & 100.0 \\
\hline
\end{tabular}

Assessments motivate students to prepare for them, motivated by their success and also serve to reduce students' anxiety about later examinations, designed to grade them. Very promptly corrected work gives the trainer the opportunity to talk constructively to the trainees about their work. Moreover the main purpose and benefit of the tests is that they quickly diagnose errors or omissions in the training process, so that corrective work can take place to make good these deficiencies (Petty,2001).This prevents "compound errors" of learning, where one week's poor learning makes the 
following week's learning all the more difficult. With the limited number of C.A.Ts per term in TIVET colleges it makes it difficult to discover trainee's weaknesses and instructional limitations for corrective help. Hence this contributes to poor performance in TIVET colleges students. Without reliable feedback training will never be effective.

A total of $188(58.8 \%)$ students agreed that the principal walks around in classes to check on how training progresses, another 217 (67.8\%) agreed that the principal assess students' classroom notes, while 264 (82.5\%) agreed that the principal encourages students to perform well. The supervision is vital for proper training and staff commitment.

The findings indicate that although Ministry of Education Officials visited the institutions at least once annually for inspection, the standard of inspection and supervision of TIVET institutes were low in Eastern and Central region. This was confirmed by all the seven principals in the study. The directorate of Quality Assurance and Standards (QAS) is responsible for quality assurance, which encompasses effective monitoring of curriculum delivery in training institutions. QAS should provide advisory services to learning institutions and other stakeholders on how to improve their training, encourage team playing that is essential and this way institutions are enabled to put in place quality assurance measures, make use of them hence institutional performance improve. Without proper and regular inspection of TIVET institutes it would be very difficult for performance to be improved.

Another significant finding is that most (71.4\%) of the principals in this study reported that teachers were to a very large extent assigned subjects that they did not study for in college. This has serious implications on the quality of teaching that take place in TIVET institutions. Teachers are the ones who play a central role in the educative process through implementing the purposefully designed curriculum to achieve the desired educational goals (Wanzare and Ward, 2000).

TIVET institutions should ensure that teachers play this role effectively by assigning them subjects that they were trained for - for lack of subject mastery can contribute to poor teaching, stemming from the teacher's lack of understanding of the topic in hand (Carre, 1995 and Shulman, 1987). In addition, TIVET trainers should receive regular in-service training so that they keep abreast with new knowledge in the information age. On this, Odhiambo (2005) notes that there is a burgeoning national debate on the quality of teaching and learning and a feeling that continuous education for teachers would lead to this quality. He continues to say that the most important purpose of a school is to provide children with equal and enhanced opportunities for learning; the most important resource a school has for achieving that purpose is the knowledge and skills of its teachers; and the most important strategy for maintaining and improving that resource is a career and professional development process for teachers.

Emerging from trainees is the fact that principals rarely visit classes to supervise instructional activity, and they rarely check on students work. Mbiti (2007) says that the principal is a key player in the design and operations of the organizational arrangements of the school. She or he is charged with the responsibility of steering the institute towards meeting its goals. As the one playing the managerial function at the institute level she or he is charged with the responsibility of providing enabling environment for an efficient and effective attainment of the organizational goals. Principals should therefore perform their internal supervision roles effectively for quality assurance plus improvement in performance among the TIVET middle level colleges.

\section{Ways of Improving the Performance of Middle Level Colleges}

The fourth objective of the study was to suggest ways of improving the performance of middle level colleges. The principals were asked to suggest possible measures that could be adopted so as to improve performance in TIVET. The factors they considered critical and requiring immediate attention included; enhancing inspection from the Ministry, maximum and adequate provision of teaching/learning resources, encourage students to be self-motivating in learning, provide in-service training to trainers and match teaching levels assignments with teacher's educational qualifications. The HoDs were asked to suggest ways that could be adopted to improve performance in TIVET, to which they gave the following suggestions: -

- Upgrade teachers by offering higher learning to them to enable match challenging tasks assigned to them

- Provide adequate training materials and provision of better facilities to ease and support training

- Introduce follow-ups for teachers and students work for corrective measures where deviations from the expected.

- Ministry of Education to employ more qualified personnel and of higher grades at the provincial and district levels

- KIE should constantly revise the syllabus to be in line with emerging trends hence motivate trainees have positive attitude towards their courses of study and thus be motivated to work harder. 
- Reduce teachers' workload and stop allocating teachers to teach subjects not covered in college and teaching trainees at their level of education. This gives teachers confidence and command respect from their trainees for the competence they portray.

- The trainers gave the following suggestions that could be adopted to improve performance in the institute:

- Provision of adequate teaching/learning materials

- Constant and regular supervision and evaluation of the institute by ministry officials

- Employ qualified teachers

- Other measures that could be taken according to trainers are as follows:

- Participatory decision-making be encouraged

- Government to support middle or low level institutes by supplying needed training facilities

- Avoid forcing students to take courses that they are not willing to do, this will be motivating to them

- Revise the current curriculum

The trainees gave the following measures as critically significant for improving TIVET Colleges' performance:

- Provide the students with adequate facilities and learning materials

- Sponsor students from poor families

- Teachers to attend classes and avoid coming late

- Day scholars should be provided with textbooks to revise while at home

- Students should take lectures seriously

- Ministry of Education should constantly monitor what transpires in the training centres.

\section{Conclusion}

The study concludes that although that there had been improvement in national examination performance for the five TTIs for the study period (2002-2006) in terms of percentage of students who registered passes, a number of factors negatively influence academic performance of TTIs. These include teacher-related factors like ill prepared and trained teachers (teachers with low qualification), lack of morale and inadequacy of teachers, student- related factors like indiscipline and lack of motivation, and self efficacy, assigning teachers subjects that they never trained for in college, and low standard of inspection and supervision of TIVET institutes in Eastern and Central region. The directorate of Quality Assurance and Standards (QAS) is responsible for quality assurance, which encompasses effective monitoring of curriculum delivery in training institutions. QAS should provide advisory services to learning institutions and other stakeholders on how to improve their training, encourage team playing that is essential and this way institutions are enabled to put in place quality assurance measures, make use of them hence institutional performance improve. Without proper and regular inspection of TIVET institutes it would be very difficult for performance to be improved.

\section{References}

Anderson, L. W. (1991). Increasing Teacher Effectiveness. UNESCO Publication.

Bandura, A. (1997). Self-efficacy: The Exercise of Self Control. New York: Freeman.

Brinker, H. D. (1988). Sociology $2^{\text {nd }}$ Ed. New York: West Publishing.

Butler, D and Winnie, P. (1995). Feedback and self - regulated learning: A Theoretical synthesis. Review of Educational researcher, 65 (3), 245-281

Campbell, R. Carbally, J. and Nystrand, R. (1983). Introduction to Education Administration $6^{\text {th }}$ Ed. Boston: Allyn and Bacon.

Carre, C, (1994). "What is to be learned in school?" In Desforges, C. (ed). An Introduction to Teaching: Psychological Perspective. Oxford: Blackwell.

Carl, R (1994). Freedom to Learn. 3rd New York: Merril.

Daily Nation, 27th September 2005. Nairobi

Docking, J. (1989). "Elton Four Questions: Some General Considerations." In Jones, N. Ed. School Management and Pupil Behaviour. London: Falmer Press.

Ergul, H. (2004). "Relationship between students achievement and academic achievement in distance education and application of Anadolu University," http://ergul.htm.April 2004.

Eshiwani, G. S. (1983). "Factors Influencing Performance among Primary and Secondary Schools Pupils in Western Province of Kenya." Nairobi Mimeo, Bureau of Educational Research. Kenyatta University.

Eshiwani, G. S. (1985). "The Kenya Teacher in the 1990s Some Reflections on Training and Professionalism." Kenyatta University Bureau of Educational Research.

Farraat, J. S. (1980) Principles and Practice of Education. Hongkong: Scheck Wah Tong Press. 
Gardner, J. (1961). Excellence; Can We Be Equal and Excellent Too? New York: Harps and Row.

Gay, L. R. (1992). Educational Research; Competence for Analysis and Application. New York: Macmillan Publishing Company.

Hellinger, P. and Hech, R. (1995). Exploring the Principals Contribution to School Effectiveness 1980-1995. Boston: Greenfield Allyn and Bacon.

Hendrikz, E.(1994). Introduction to Educational Psychology. London :Macmillan Education Ltd.

Hopkins, D. Ainscow, M., West, M (1997). "School improvements-propositions for action." In: Harris A, Bennet N. \& Preedy, M. Organizational Effectiveness and Improvement in Education. Buckingham: Open University Press.

Hustler D. And Me Intyre, D (ed), (1996) Developing competent Teachers: Approaches to Professional Competence in Teacher Education. London: David Fulton.

Ingule, F. O., Ruthie, C. R. and Ndambuki, P. W. (1996). Introduction to Educational Psychology. Nairobi: East African Educational Publishers.

Kanore, M.G. (2000) challenges in improving Teacher Education in Kenya. Nairobi.

Kellaghan, T. and Greaney, V. (2001). Fundamentals of Educational Planning: Using assessment to improve the quality of education. Paris: UNESCO.

Kimalu, P. K., Nafula, N., Manda, D. K., Mwabu, G. \& Kimenyi, M.S. (2001). Education Indicators in Kenya. KIPPRA Paper.

Kimani, G. N. (1983). A Study of Secondary Technical School Student's and_Teachers' Attitudes toward Technical Education Programme in Kenya. Master of Arts Thesis. University of Nairobi.

Kimemia, J. (1989). "The role of the inspectorate in Kenya Secondary Education and Professional conflicts in Education Management." Unpublished Doctorate Dissertation University of London.

Kiragu, F. Et al (1978). Teacher Training and Students Achievement in Less Developed Countries. Washington DC.

Kombo D. K. and Tromp, D. L. A. (2006). Proposals and Thesis Writing: An Introduction $2^{\text {nd }}$ ed. Nairobi: Paulines Publishers Africa.

Kombo, D. K. (1988). "Factors influencing Students Poor Performance in the KCSE Examination among Harambee Secondary Schools in Kathiani Division of Machakos District." Master of Arts Thesis. Kenyatta University.

Kothari, C. R. (2003). Research Methodology: Methods and Techniques Revised Ed. New Delhi: Willy Eastern Ltd.

Kovach, (2000). Self regulated strategies in an J.C accounting principles course: Effects of students achievement. Mid - Western Educational Research Association. Chicago.

Lane, W. R. And Corwin, R. G. (1966). Foundations of Educational Administration: A Behavioural Analysis. New York: The Macmillan Company.

Mbiti, D. M. (2007). Foundations of School Administration (Ed.). Nairobi: Oxford University Press East Africa Ltd.

MOST, (2007). Study Report on Formulation of legal Framework in the Kenyan TIVET System. Nairobi.

Mugenda, M. O. and Mugenda, G. A. (1999). Research Methods Qualitative and Quantitative Approaches. Nairobi: Acts Press.

Nachmias, C. F. and Nachmias, D (2003). Research Methods in the Social Sciences $5^{\text {th }}$ ed. London: St. Martins Press.

Ogula, P. O. (1995). A Handbook of Educational Research. Nairobi: New Kemit Publishers.

Okumbe, J. A. (1998). Educational Management Theory and Practice. Nairobi: University Press. Nairobi: Education Research and Publication.

Olembo, J .0., Wanga, P. E. and Kiragu, N. M. (1992). Management in Education . Education Research and Publication (ERAP).

Petty, G. (2001). Teaching Today: A Practical Guide 2nd Ed. Cheltenham: Nelson Thomrnes Ltd.

Republic of Kenya (1976). Report of National Committee on Education Objectives and Policies. Nairobi: Government Printer.

Republic of Kenya. (1988). The Presidential Working Party on Education and Manpower Training for the Next Decade and Beyond (Kamunge Report). Nairobi: Government Printer.

Republic of Kenya (2001). National Development Plan (2002-2008) Effective_Management for Sustainable Economic Growth and Poverty Reduction. Nairobi: Government Printer.

Republic of Kenya. (2005). MOEST Sessional Paper No 1 of 2005 A Policy Framework on Educational Training and Research for the $21^{\text {st }}$ Century; Meeting the Challenges of Education, Training and Research in Kenya in $21^{\text {st }}$ Century. Nairobi:Government Printer.

Republic of Kenya. (2006). Economic Survey. Nairobi: Government Printer.

Republic of Kenya. (1965). The Kenya Education Commission Report (Ominde Report). Nairobi: Government Printer

Republic of Kenya. (1981). Second University in Kenya. Report of the Presidential Working Party. Nairobi: Government Printer.

Rowland, V. and Birkett, K. (1992). Personal Effectiveness for Teachers. Great Britain: Simon and Schuster Education.

Shiefekbein and Simons (1981). "The Determinants of School Achievement. A review of the research for developing countries". Unpublished paper.

Shiundu, J. S. And Omulando, S. J.(1982). Curriculum Theory and Practice in Kenya. Nairobi: Oxford University Press.

Shulman, L. S. (1987). Knowledge and Teaching: Foundations of the New Reform: Harvard Educational Review Vol. 57 ppl-22.

Shunk, D.H. (1989). "Social Cognitive Theory and self - regulated learning." In: Zimmerman, B. J., and Schunk, D. H. (eds), Self regulated learning and academic achievement: Theory, Research and Practice (pp. 83 - 110). New York: Springer - Verlag.

Sogomo, B. K. (2000)."Keynote address to Principals of Training Teacher Colleges on teacher education." Paper presented during a workshop for Principals of Teacher Training Colleges in Kenya. Nairobi.

TIVET. (2003). Report on Rapid Appraisal on the Status of Technical Education and Vocational Training TVET. Nairobi.

UNESCO (2003). National Conference on Education and Training. UNESCO.

UNESCO (2005). Challenges of Implementing Free Primary Education in Kenya: An Assessment Report. Nairobi: UNESCO. 